\title{
РОЛЬ МЕТЕОРОЛОГИЧЕСКОГО ФАКТОРА В МНОГОЛЕТНЕЙ ДИНАМИКЕ ЧИСЛЕННОСТИ КУКУРУЗНОГО МОТЫЛЬКА Ostrinia nubilalis Hbn. В КРАСНОДАРСКОМ КРАЕ: АНАЛИЗ ТАБЛИЦ ВЫЖИВАЕМОСТИ
}

\section{А.Н. ФРОЛОВ, И.В. ГРУШЕВАЯ}

Кукурузный мотылек Ostrinia nubilalis Hbn. - один из наиболее опасных вредителей кукурузы. Хотя важная роль метеорологических условий, в первую очередь температуры и влажности воздуха, многократно продемонстрирована в отношении распространения, численности и сроков развития кукурузного мотылька, точность существующих моделей прогноза размножения вредителя остается невысокой. Цель нашей работы состояла в сопоставлении метеорологических данных с демографическими показателями, характеризующими многолетние колебания численности локальной популяции кукурузного мотылька, и выявлении наиболее значимых критериев метеорологической информации для прогноза динамики численности вредителя. Наблюдения за динамикой численности кукурузного мотылька проводили в окрестностях пос. Ботаника (Краснодарский край, Гулькевичский р-н; 4512'51" с.ш. и 4047'41" в.д.) в 1994-2018 годах, причем полученные за сезон 2018 года материалы были использованы исключительно для верификации зависимости, установленной на массиве данных за 1994-2017 годы. Посредством периодических учетов численности оценивали плотности вредителя на всех стадиях его жизненного цикла - от яйца до имаго. Для анализа использовали метеорологическую информацию, поступавшую с Отрадо-Кубанской метеостанции, расположенной в центре территории, на которой размещались учетные посевы. Смертности насекомых за разные периоды развития (яиц, гусениц I-II и III-V возрастов, куколок, имаго) представляли в виде разности логарифмов плотностей: $\mathrm{K}=\log \mathrm{N}_{1}-\log \mathrm{N}_{2}$, где $\mathrm{N}_{1}$ и $\mathrm{N}_{2}$ - плотность насекомых за соответствующие учетные периоды. Смертность за генерацию представляли в виде $K=\log \mathrm{N}_{\mathrm{o}}-\log \mathrm{N}_{\mathrm{f}}$, где $\mathrm{N}_{\mathrm{o}}$ и $\mathrm{N}_{\mathrm{f}}-$ плотность яиц и яйцекладущих самок текущего поколения. Индекс размножения за поколение рассчитывали по формуле: $\mathrm{I}=\mathrm{N}_{\mathrm{t}+1} / \mathrm{N}_{\mathrm{t}}$, где $\mathrm{N}_{\mathrm{t}}$ и $\mathrm{N}_{\mathrm{t}+1}-$ плотность яиц текущего $(\mathrm{t})$ и следующего $(\mathrm{t}+1)$ поколений. В зоне проведения работ в течение сезона развивалось два поколения насекомого, причем в первых поколениях численность обычно возрастала, а во вторых - снижалась. Достоверная связь демографических характеристик насекомого с метеорологическими факторами обнаружилась только в интервале, ограниченном III декадой мая-I декадой июня, когда обычно отмечались массовая откладка яиц и отрождение гусениц I возраста первых генераций вредителя. Смертность яиц оказалась связана с температурой воздуха отрицательной зависимостью, а с влагой (как в капельно-жидком состоянии, так и в виде водяного пара) - положительной. Влияние метеорологических факторов на демографические показатели вредителя во втором поколении, в том числе во время откладки яиц и отрождения гусениц, не выявлено. Вероятно, в этот период посевы кукурузы уже сформировывали мощный стеблестой с микроклиматом, благоприятствующим развитию насекомого. Таким образом, III декаду мая-I декаду июня следует рассматривать в качестве единственного критического периода в развитии вредителя в регионе. По оригинальным данным построена 3D-контурная линейная диаграмма зависимости смертности яиц кукурузного мотылька первого поколения от среднесуточной температуры воздуха и относительной влажности воздуха в последнюю декаду мая, представляющая интерес с точки зрения разработки уточненной модели краткосрочного прогноза размножения вредителя в Краснодарском крае.

Ключевые слова: кукурузный мотылек, динамика численности, демография, смертность яиц, температура воздуха, влажность воздуха, Краснодарский край.

Кукурузный мотылек Ostrinia nubilalis Hbn. - один из наиболее опасных вредителей кукурузы, потери урожая зерна от которого в Восточной Европе до сих пор весьма высоки (1-4). Несмотря на то, что этому насекомому посвящено значительное число публикаций как в России (57), так и за рубежом (8-11), многие особенности его экологии остаются недостаточно раскрытыми (12). Так, убедительно показана весомая роль метеорологических условий, в первую очередь температуры и влажности, в распространении и численности, а также сроках развития кукурузного мотылька (13-17). В то же время точность прогноза, в основу которого поло- 
жена метеорологическая информация, остается невысокой (18).

В основе отечественной теории фитосанитарного прогноза лежит закон толерантности В. Шелфорда (Victor E. Shelford), основанный на эффектах лимитирующих факторов среды, действующих в критические периоды жизненного цикла вредного вида (19). Результаты изучения популяционной генетики представителей рода Ostrinia (1) дают основание предполагать, что в жизненном цикле кукурузного мотылька выделяются следующие критические периоды: окукливание перезимовавших гусениц; спаривание и откладка яиц бабочками; начало питания гусениц (20). Подразумевается, что жизнеспособность популяции в эти периоды определяют метеорологические факторы: среднесуточная температура и количество осадков за промежуток времени от перехода температуры через $11{ }^{\circ} \mathrm{C}$ до начала окукливания перезимовавших гусениц; сумма осадков во время откладки яиц бабочками; отсутствие ливней, сильных ветров, высоких температур и прочих экстремальных метеорологических явлений в начальный период питания гусениц (20).

Выявление закономерностей динамики численности вредных видов насекомых - важнейший аспект исследований по защите растений, поскольку достоверность прогнозов размножения вредных объектов определяется степенью изученности влияющих на их численность факторов, а точность прогнозов зависит от адекватности использованных моделей (19).

В представленной работе мы впервые доказали определяющий вклад гибели яиц кукурузного мотылька в динамике численности первого в сезоне поколения вредителя. Достоверная связь смертности насекомого с метеорологическими факторами обнаружена в интервале, ограниченном III декадой мая-I декадой июня, когда обычно происходят массовая откладка яиц и отрождение гусениц 1-го возраста первых генераций.

Цель нашей работы состояла в сопоставлении метеорологических данных с демографическими показателями, характеризующими многолетние колебания численности локальной популяции кукурузного мотылька, и выявлении наиболее значимых критериев метеорологической информации для прогноза динамики численности вредителя.

Методика. Наблюдения за динамикой численности кукурузного мотылька Ostrinia nubilalis проводили в окрестностях пос. Ботаника (Краснодарский край, Гулькевичский р-н; 45¹2'51" с.ш. и 4047'41" в.д.) в 19942018 годах, причем полученные за сезон 2018 года материалы были использованы исключительно для верификации зависимости, установленной на массиве данных за 1994-2017 годы. В качестве учетной территории был выбран научный севооборот Кубанской опытной станции ВИР (КОС ВИР) общей площадью 284 га. С 2014 года учетами были также охвачены примыкающие к научному севообороту поля НПО «КОС-МАИС» общей площадью 500 га. В центре научного севооборота КОС ВИР размещалась Отрадо-Кубанская метеостанция, откуда ежесуточно поступала стандартная метеорологическая информация.

Учеты численности кукурузного мотылька проводили ежегодно в среднем на 6 (минимум на 3 и максимум на 14) участках кукурузы общей площадью от 18,4 до 175,0 га, где выращивали районированные и перспективные гибриды, а также их родительские формы. Ассортимент возделываемых генотипов кукурузы менялся соответственно Государственному реестру допущенных к использованию селекционных достижений (21). На учетных посевах использовали все принятые в зоне агротехнические приемы (обработку почвы, посев, внесение гербицидов, 1-2 междурядные 
культивации). Посев семян, как правило, осуществляли в оптимальные сроки. Сформированная густота посева на участках варьировала от 2,8 до 7,8 растений на $1 \mathrm{~m}^{2}$, плотность популяции насекомых оценивали в расчете на $1 \mathrm{~m}^{2}$ посева. Именно такой способ расчета плотности представляется единственно возможным для демографического описания полного цикла сезонной динамики численности насекомых, поскольку развитие особей 2го поколения завершается после их зимовки в растительных остатках, сохраняющихся на полях после уборки урожая.

Периодические учеты численности (21-23 за сезон) охватывали жизненный цикл насекомого от яйца до имаго. Учеты перезимовавших особей (то есть 2-го поколения предыдущего сезона) проводили на полях, которые были заняты кукурузой в прошлом году. На таких участках дважды (до начала окукливания и по завершении вылета имаго) оценивали плотность и смертность перезимовавших гусениц, куколок и имаго в растительных остатках. Плотность распределения перезимовавших и ушедших на зимовку гусениц определяли на площадках размером 0,7-1,0 м² (по 2025 площадок на участок), выбранных случайным образом. Плотность размещения яиц 1-го (май-июнь) и 2-го (июль-август) поколений оценивали на постоянных (в течение сезона) учетных площадках, состоящих, как правило, из 10 растений, первое и последнее из которых маркировали. Число таких площадок на участке варьировало от 9 до 25 в зависимости от площади последнего. В период лёта имаго растения на площадках тщательно осматривали каждые 3-5 сут, местоположение найденных кладок яиц маркировали. С помощью ручной лупы подсчитывали число яиц в кладке, затем оценивали число яиц, из которых отродились гусеницы (22). Суммарное количество яиц, обнаруженных на площадках при проведении серий периодических учетов, использовали для расчета плотности размещения отложенных яиц на участке. По завершении периода яйцекладки проводили серию учетов численности гусениц на растениях, для чего растения вскрывали на случайным образом выбранных площадках размером 0,7-1,5 м ${ }^{2}$ из 5-10 растений каждая. Число таких площадок варьировало в посеве кукурузы от 15 до 35 в зависимости от размера поля. Обнаруженные на площадке сорные растения также осматривали, поскольку они могли быть заселены гусеницами вредителя.

Плотность имаго оценивали по экзувиям. Численность яйцекладущих самок вычисляли как частное от деления средневзвешенной плотности яиц следующей генерации на 225 (22); полученная величина характеризовала плотность имаго, нормализованных по соотношению полов (1q:1ð) и средней плодовитости самки; по результатам многолетних (1975-2004 годы) подсчетов яиц, отложенных бабочками в лабораторных условиях, среднюю плодовитость у оплодотворенной самки принимали равной 450 яйцам. Среднюю за поколение плотность яиц, гусениц, куколок, имаго и яйцекладущих самок кукурузного мотылька рассчитывали средневзвешенно по площадям, занимаемым учетными посевами кукурузы.

Смертности насекомых за разные периоды развития (яиц, гусениц I-II и III-V возрастов, куколок, имаго) представляли в виде разности логарифмов плотностей: $\mathrm{K}=\log \mathrm{N}_{1}-\log \mathrm{N}_{2}$, где $\mathrm{N}_{1}$ и $\mathrm{N}_{2}-$ плотность насекомых за соответствующие учетные периоды $(23,24)$. Смертность за генерацию представляли в виде $\mathrm{K}=\log \mathrm{N}_{\mathrm{o}}-\log \mathrm{N}_{\mathrm{f}}$, где $\mathrm{N}_{\mathrm{o}}$ и $\mathrm{N}_{\mathrm{f}}-$ плотность яиц и яйцекладущих самок текущего поколения. Перед логарифмированием величины плотности пересчитывали на 1000 м² посева кукурузы, чтобы избежать возникновения отрицательных значений логарифмов при низкой 
плотности фитофага. Индекс размножения за поколение рассчитывали по формуле: $\mathrm{I}=\mathrm{N}_{\mathrm{t}+1} / \mathrm{N}_{\mathrm{t}}$, где $\mathrm{N}_{\mathrm{t}}$ и $\mathrm{N}_{\mathrm{t}+1}-$ плотность яиц текущего (t) и следующего $(\mathrm{t}+1)$ поколений $(6)$.

Bce расчеты выполняли с помощью программного пакета Statistica 10.0 («StatSoft, Inc.», США). В таблицах представлены средние $(M)$, максимальные $(\max )$ и минимальные $(\min )$ значения, стандартные отклонения $( \pm \mathrm{SD})$, а также коэффициенты вариации $(C v)$ и корреляции $(r)$; зависимости между эффектами выявляли с помощью корреляционного и регрессионного анализов, достоверность связей при уровне значимости $\mathrm{p}<0,05$ оценивали с помощью $t$-критерия Стьюдента и $F$-критерия Фишера.

Результаты. Многолетней тенденцией был постепенный, но неуклонный рост степени устойчивости новых гибридов кукурузы к вредителю в период развития первого поколения (21). Так, если в 1994-1997 годах средний показатель поврежденности вредителем листьев по шкале 1-9 баллов (25) для образцов кукурузы, выращиваемых на 18 учетных посевах, варьировал в пределах 3-7 баллов (при среднем значении 5,4 балла и коэффициенте вариации 27,1 \%), то в 2014-2018 годах на 14 учетных посевах он колебался от 2 до 5 баллов (в среднем 3,2 балла с коэффициентом вариации $34,9 \%$ ).

1. Плотность распределения особей кукурузного мотылька (Ostrinia nubilalis Hbn.) за учетные периоды развития в первой и второй генерациях насекомого (окрестности пос. Ботаника, Краснодарский край, 1994-2017 годы)

\begin{tabular}{|c|c|c|c|}
\hline \multirow{3}{*}{$\begin{array}{l}\text { Учетный } \\
\text { период }\end{array}$} & \multicolumn{3}{|c|}{ Плотность } \\
\hline & \multicolumn{2}{|c|}{ в расчете на 1 м $^{2}$ посева } & \multirow{2}{*}{ в расчете на 1 растение, $M \pm \mathrm{SD}$} \\
\hline & $M \pm \mathrm{SD}$ & $\min -\max$ & \\
\hline \multicolumn{4}{|c|}{ 1-е поколе н и е } \\
\hline $\mathrm{O}$ & $32,81 \pm 30,70$ & $2,87-133,60$ & $6,31 \pm 5,95$ \\
\hline L1 & $20,14 \pm 16,81$ & $1,94-67,35$ & $3,87 \pm 3,25$ \\
\hline L2 & $4,24 \pm 4,00$ & $0,09-17,07$ & $0,82 \pm 0,78$ \\
\hline $\mathrm{P}$ & $2,52 \pm 2,66$ & $0,05-12,22$ & $0,48 \pm 0,52$ \\
\hline A & $1,62 \pm 1,62$ & $0,04-6,90$ & $0,31 \pm 0,33$ \\
\hline FO & $0,55 \pm 0,50$ & $0,02-1,82$ & $0,11 \pm 0,12$ \\
\hline \multicolumn{4}{|c|}{ 2-е поколе ни е } \\
\hline $\mathrm{O}$ & $108,77 \pm 107,22$ & $4,92-408,45$ & $20,92 \pm 20,66$ \\
\hline L1 & $47,02 \pm 43,77$ & $2,32-163,20$ & $9,04 \pm 8,48$ \\
\hline L2 & $17,56 \pm 16,13$ & $1,17-57,77$ & $3,38 \pm 3,12$ \\
\hline $\mathrm{Pa}$ & $1,52 \pm 1,41$ & $0,13-5,11$ & - \\
\hline $\mathrm{A}^{\mathrm{a}}$ & $0,97 \pm 1,08$ & $0,10-4,11$ & - \\
\hline $\mathrm{FO}^{\mathrm{a}}$ & $0,17 \pm 0,15$ & $0,01-0,59$ & - \\
\hline \multicolumn{4}{|c|}{$\begin{array}{l}\text { П р и м е ч а н и е. O - яйца, L1 и L2 - соответственно отродившиеся из яиц и питающиеся на растени- } \\
\text { ях гусеницы III-V возрастов, P - куколки, А - имаго, FO - яйцекладущие самки, а - в следующем } \\
\text { сезоне после перезимовки. Прочерки означают, что растения на поле отсутствовали. }\end{array}$} \\
\hline
\end{tabular}

Данные наблюдений за 1994-2017 годы свидетельствуют о широкой вариации численности кукурузного мотылька на кукурузе в пределах учетной территории, причем характер колебаний плотности насекомых 1-го и 2-го поколений существенно различался (табл. 1). Так, в первых генерациях плотность яиц и питающихся на растениях гусениц, как правило, были существенно ниже, чем во вторых поколениях, тогда как плотности перезимовавших куколок, имаго и яйцекладущих самок - значительно выше, что было обусловлено дополнительной смертностью насекомых 2-го поколения во время уборки, осенних и весенних обработок почвы, а также перезимовки (см. табл. 1). Значения индекса размножения насекомых также варьировали в широких пределах (рис. 1): по 1-му поколению - от 0,34 до 13,04 (в среднем 4,24), по 2-му - от 0,02 до 1,85 (в среднем 0,65). Иными словами, если в 1-м поколении у кукурузного мотылька обычно происходило нарастание численности, то во 2-м она снижалась. 
Хотя численность вредящий стадии кукурузного мотылька (взрослых гусениц) в 1-м поколении обычно ниже, чем во 2-м, вред, наносимый растениям особями 1-й генерации обычно существенно выше (26-28). В этой связи практический интерес представляет анализ динамики численности вредителя именно в период развития 1-го поколения, когда численность подвержена резким колебаниям и роль метеорологических факторов, действующих в критические периоды развития насекомого, вполне ожидаема (20).

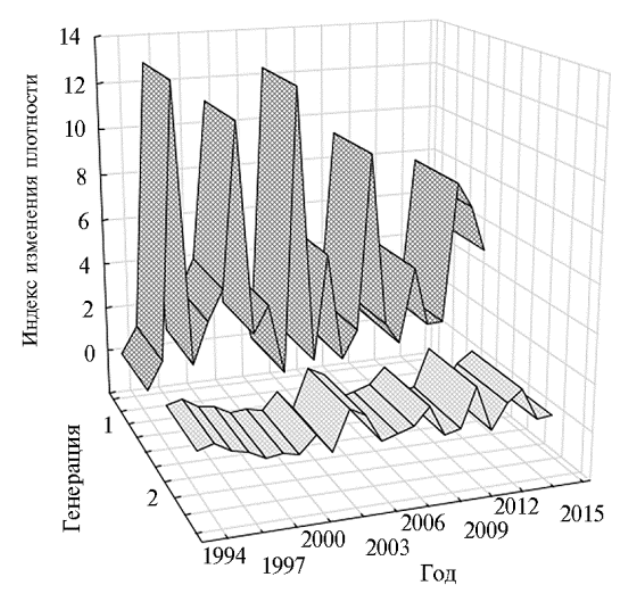

Рис. 1. Индекс размножения (I) кукурузного мотылька (Ostrinia nubilalis Hbn.) на учетной территории за периоды развития 1-й и 2-й генераций вредителя (окрестности пос. Ботаника, Краснодарский край, 1994-2017 годы).

В зависимости от условий года сроки прохождения тех или иных стадий развития кукурузного мотылька существенно сдвигались. Так, время начала окукливания гусениц перезимовавшего поколения варьировало в весьма широких пределах (от первых чисел до конца апреля). Период откладки яиц перезимовавшими самками, начало которого на среднеспелых генотипах (ФАО 350-400) приурочено к фазе средней листовой воронки (5-6 листьев), как правило, начиналось с I-III декады мая и завершалось к середине июня-началу июля с пиком в III декаде мая-I декаде июня. Развитие гусениц 1-го поколения обычно заканчивалось к началу августа, окукливание основной части популяции охватывало период с начала июля до середины августа, массовый лёт имаго 1-го поколения наблюдался с середины июля до середины августа. Откладка яиц самками 1-го поколения начиналась на растениях кукурузы со второй половины июля до середины августа с пиком, наблюдаемым в конце июля-начале августа. Практически ежегодно некоторая часть гусениц 2-го поколения (обычно в пределах 0-5 \%, максимально до 30 \%) окукливалась, давая начало особям 3-го поколения. Их большая часть в условиях дефицита корма и скорого наступления холодов погибала, поэтому в общей массе готовых к перезимовке гусениц особи 3-го поколения обычно составляли не более 2,0 \% от особей 2-го с колебаниями по сезонам от 0 до 7,6 \%.

2. Статистически значимые $(\mathrm{p}<0,05)$ коэффициенты корреляции $(r)$ смертности (эффекты K) за разные периоды развития первой генерации кукурузного мотылька (Ostrinia nubilalis Hbn.) с метеорологическими факторами (окрестности пос. Ботаника, Краснодарский край, 1994-2017 годы)

\begin{tabular}{|c|c|c|c|}
\hline \multirow{2}{*}{ Период } & \multicolumn{3}{|c|}{ Смертность, K } \\
\hline & яиц & гусениц I-II возрастов & поколения в целом \\
\hline \multicolumn{4}{|c|}{ Температура воздух а, ${ }^{\circ} \mathrm{C}$} \\
\hline Май, III декада & 0,634 & & 0,564 \\
\hline \multicolumn{4}{|c|}{ Вла жность воздуха, } \\
\hline Май, ІІІ декада & $-0,568$ & & $-0,462$ \\
\hline Июнь, I декада & $-0,542$ & $-0,437$ & $-0,590$ \\
\hline \multicolumn{4}{|c|}{ О с а д к и, мм } \\
\hline Июнь, I декада & $-0,435$ & & $-0,618$ \\
\hline
\end{tabular}

По результатам наблюдений за 1994-2017 годы был проведен корреляционный анализ смертности насекомых, измеренной эффектами К, со 
среднедекадными значениями температуры и влажности воздуха, а также суммой осадков за два периода (март-конец июня и II декада июля-II декада августа) (табл. 2).

Достоверные связи демографических характеристик насекомого с метеорологическими факторами были обнаружены лишь в первый временной интервал (с III декады мая по I декаду июня), то есть когда происходила массовая откладка яиц и отрождение гусениц 1-й генерации (см. табл. 2). При этом наиболее часто достоверная связь метеорологических факторов с демографическими показателями популяции обнаруживалась в период развития яиц: корреляционный анализ свидетельствует о существенном негативном влиянии повышенных температур воздуха и позитивном эффекте влаги, как капельно-жидкой, так и водяного пара, на выживаемость яиц (см. табл. 2). Влияние влажности воздуха на выживаемость гусениц младших возрастов было менее выражено, тогда как вариация метеорологических факторов вообще не обнаруживала статистически значимых корреляционных зависимостей с выживаемостью гусениц старших возрастов, куколок или имаго.

3. Базовые статистические показатели смертности (эффектов К) кукурузного мотылька (Ostrinia nubilalis Hbn.) в разные периоды воздействия и их корреляция со смертностью за период развития генерации в целом (окрестности пос. Ботаника, Краснодарский край, 1994-2017 годы)

\begin{tabular}{|c|c|c|c|c|c|c|}
\hline \multirow{3}{*}{ Показатель } & \multicolumn{6}{|c|}{ Эффекты смертности (К) по периодам развития } \\
\hline & \multirow{2}{*}{\begin{tabular}{|l|} 
генерация \\
в целом
\end{tabular}} & \multirow{2}{*}{ яйца } & \multicolumn{2}{|c|}{ гусеницы } & \multirow[b]{2}{*}{ куколки } & \multirow[b]{2}{*}{ имаго } \\
\hline & & & I-II возрастов & III-V возрастов & & \\
\hline$M \pm \mathrm{SD}$ & $1,862 \pm 0,436$ & $0,207 \pm 0,229$ & $0,726 \pm 0,367$ & $0,268 \pm 0,184$ & $0,199 \pm 0,138$ & $0,463 \pm 0,412$ \\
\hline $\min -\max$ & $1,225-2,815$ & $0,035-0,876$ & $0,039-1,366$ & $0,053-0,703$ & $0,007-0,466$ & $-0,173-1,505$ \\
\hline$C v, \%$ & 23,42 & 110,96 & 50,55 & 68,64 & 69,39 & 89,08 \\
\hline \multirow{2}{*}{\multicolumn{2}{|c|}{$\begin{array}{l}r \text { (со смертностью за пери- } \\
\text { од развития генерации) } \\
\end{array}$}} & $0,70^{*}$ & 0,23 & 0,23 & $-0,09$ & 0,39 \\
\hline & & корреляции & тистически 3 & Mо $(\mathrm{p}<0,05)$ & & \\
\hline
\end{tabular}

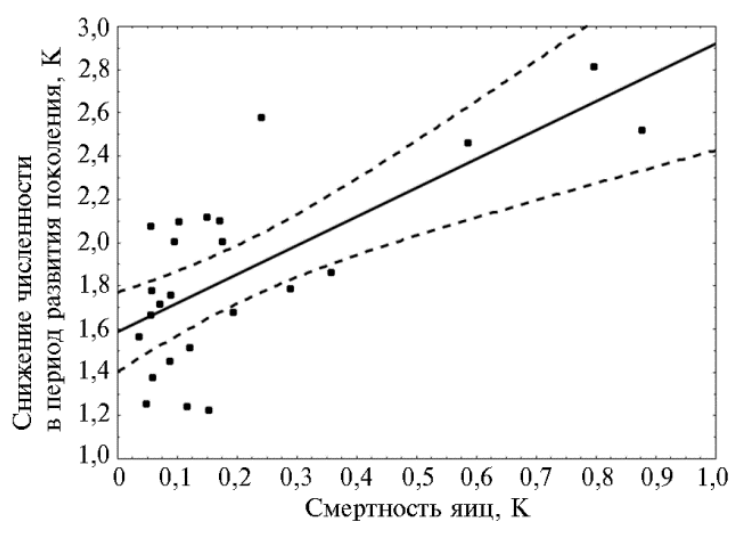

Рис. 2. Связь смертности за периоды развития яиц и целого поколения (от яйца до имаго), измеренных эффектами $\mathrm{K}$, для первых в сезоне генераций кукурузного мотылька (Ostrinia nubilalis Hbn.) (окрестности пос. Ботаника, Краснодарский край, 1994-2017 годы).

Внутристеблевой образ жизни вредителя - несомненно, один из факторов, смягчающих эффект погодных воздействий на жизнеспособность насекомого. Во второй критический период, то есть во время окончания развития 1-го поколения и начала развития 2-го достоверной связи метеорологических факторов с демографическими показателями насекомого мы не выявили, вероятно, потому что к этому времени посевы кукурузы формировали мощный стеблестой с микроклиматом, благоприятствующим размножению насекомого (29). Кроме того, во второй половине вегетационного периода численность вредителя нередко подпадала под мощный пресс паразитических насекомых (30), что могло оказывать сглаживающее воздействие на эффекты метеорологических факторов.

Полученные результаты свидетельствуют о том, что III декада 
мая-I декада июня могут рассматриваться в качестве единственного критического периода в развитии вредителя на модельной территории, расположенной в восточной части Краснодарского края. В этот критический период погодные условия оказывали сильное воздействие на развитие яиц и в меньшей степени - на жизнеспособность отродившихся из яиц гусениц. Корреляционный (табл. 3) и регрессионный (рис. 2) анализы свидетельствуют о том, что смертность яиц вносила наиболее весомый вклад в общую смертность особей 1-го поколения. Этот вывод вполне очевиден, поскольку значение того или иного фактора в динамике численности определяется не столько интенсивностью, сколько вариабельностью его воздействия (24).

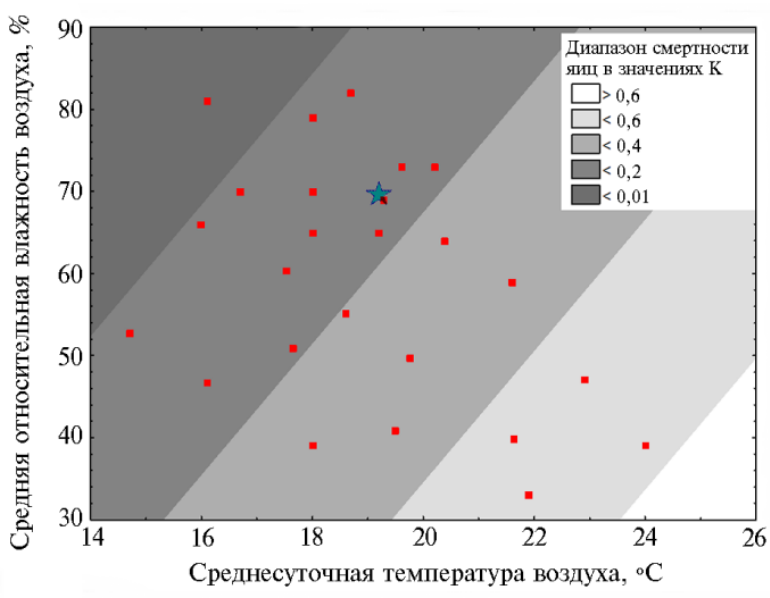

Рис. 3. 3D-контурная линейная диаграмма зависимости между смертностью яиц кукурузного мотылька (Ostrinia nubilalis Hbn.) 1-го поколения, оцененной эффектами К, и метеорологическими условиями III декады мая. Фактические значения температур и влажности воздуха, по которым строили диаграмму, обозначены красными кружками. Звездочкой отмечено сочетание значений среднесуточной температуры воздуха $19,3{ }^{\circ} \mathrm{C}$ и относительной влажности воздуха $70 \%$, при которых $\mathrm{K}=0,093$ (окрестности пос. Ботаника, Краснодарский край, 2018 год).

Поскольку период откладки яиц 1-го поколения представляет собой важнейший этап в динамике численности насекомого, построенная 3D-контурная линейная модель зависимости смертности вредителя, выраженной эффектами К, от метеорологических условий (среднесуточной температуры и относительной влажности воздуха в III декаде мая), представляет интерес с точки зрения разработки уточненных моделей прогноза численности вредителя. Провизорная верификация модели метеорологическими данными и демографическими показателями кукурузного мотылька за 2018 год дала положительный результат (рис. 3).

Детально динамику численности кукурузного мотылька в многолетнем аспекте изучали в Северной Америке - в штате Миннесота (США) в 1948-1970 годах и в провинции Онтарио (Канада) в 1957-1965 годах. Роль ключевых факторов в динамике численности насекомого в этих регионах играли доля окукливавшихся летом гусениц (штат Миннесота) и способность самок реализовать яйцепродукцию (провинция Онтарио) (6). Важно отметить, что в обоих случаях была выявлена строгая зависимость динамики численности вредителя от метеорологических факторов, действовавших в критические периоды развития насекомого. Что касается обитающих в Европе популяций кукурузного мотылька, то динамика их численности также существенным образом зависит от абиотических факторов, в первую очередь температуры $(31,32)$. Известно, что температура оказывает определяющее воздействие на фенологию насекомого, и это обстоятельство позволяет рассчитывать на создание математических моделей, прогнозирующих сроки проведения защитных истребительных мероприятий против вредителя (33). Кроме того, на основе температурных зависимостей разрабатываются модели, предсказывающие изменения ареала и зон 
вредоносности кукурузного мотылька, а также его численности в условиях глобального потепления климата (34). В контексте перечисленного полученные нами данные раскрывают новые аспекты причинно-следственных связей между вариацией погодно-климатических факторов и динамикой численности насекомого. Построение таблиц выживаемости позволяет выявлять природу колебаний численности и выявлять те факторы, которые наиболее значимо влияют на динамику популяции вредителя. Понимание того, как и почему меняется численность живых организмов во времени и пространстве - одна из важнейших задач теоретической и прикладной экологии $(35,36)$.

Таким образом, в зависимости от экологических условий ключевые факторы динамики численности популяций кукурузного мотылька существенно различаются. В восточной части Краснодарского края для этого вредителя единственным фактором динамики численности, связь которого с метеорологическими условиями статистически подтверждена, оказалась смертность яиц и в меньшей степени - отродившихся гусениц в первых поколениях в сезоне. Построенная контурная диаграмма зависимости смертности яиц кукурузного мотылька первого поколения от среднесуточной температуры воздуха и относительной влажности воздуха за последнюю декаду мая, представляет интерес для усовершенствования существующих технологий краткосрочного прогноза размножения вредителя в Краснодарском крае.

\section{ЛИТЕРАТУРА}

1. Фролов А.Н. Изменчивость кукурузного мотылька и устойчивость к нему кукурузы. Автореф. докт. дис. СПб, 1993.

2. Быковская А.В. Биологическое обоснование и разработка мероприятий по защите кукурузы oт стеблевого кукурузного мотылька (Ostrinia nubilalis Hbn.) в Беларуси. Автореф. канд. дис. Прилуки, 2015.

3. Колесников Л.О., Васильев А.А. Стеблевой мотылек (Ostrinia nubilalis Hbn.) и его вредоносность на промышленных посевах современных гибридов кукурузы. Вісник Полтавської державної аграрної академії, 2017, 1-2: 34-37.

4. Szőke C., Zsubori Z., Pók I., Rácz F., Illés O., Szegedi I. Significance of the European corn borer (Ostrinia nubilalis Hübn.) in maize production. Acta Agronomica Hungarica, 2002, 50(4): 447-461 (doi: 10.1556/AAgr.50.2002.4.8).

5. Серапионов Д.А., Фролов А.Н. Заселенность кукурузы кукурузным мотыльком первого поколения и майские осадки в Краснодарском крае: картирование и анализ с помощью ГИС. Вестник защиты растений, 2008, 2: 34-37.

6. Фролов А.Н., Грушевая И.В. Неслучайность многолетних колебаний численности кукурузного мотылька, Ostrinia nubilalis (Hbn.) (Lepidoptera, Crambidae), в Краснодарском крае. Энтомологическое обозрение, 2019, 98(1): 49-64 (doi: 10.1134/S0367144519010052).

7. Фролов А.Н., Рябчинская Т.А. К вопросу о причинах низкой аттрактивности синтетических феромонов кукурузного мотылька в новых северных очагах вредоносности насекомого на кукурузе. Вестник защиты растений, 2018, 1(95): 5-11 (doi: 10.31993/2308-64592018-1(95)-5-11).

8. O'Rourke M.E., Sappington T.W., Fleischer S.J. Managing resistance to Bt crops in a genetically variable insect herbivore, Ostrinia nubilalis. Ecological Applications, 2010, 20(5): 1228-1236 (doi: 10.1890/09-0067.1).

9. Laurent P., Frérot B. Monitoring of European corn borer with pheromone-baited traps: review of trapping system basics and remaining problems. Journal of Economic Entomology, 2007, 100(6): 1797-1807 (doi: 10.1093/jee/100.6.1797).

10. Blandino M., Scarpino V., Vanara F., Sulyok M., Krska R., Reyneri A. Role of the European corn borer (Ostrinia nubilalis) on contamination of maize with 13 Fusarium mycotoxins. Food Additives \& Contaminants: Part A, 2015, 32(4): 533-543 (doi: 10.1080/19440049.2014.966158).

11. Lassance J.-M. Journey in the Ostrinia world: from pest to model in chemical ecology. Journal of Chemical Ecology, 2010, 36(10): 1155-1169 (doi: 10.1007/s10886-010-9856-5).

12. Фролов А.Н. Закономерности динамики численности вредителей и фитосанитарный 
прогноз. Вестник защиты растений. 2019, 3(101): 4-33 (doi: 10.31993/2308-6459-20193(101)-4-33).

13. Фролов А.Н. Географическая изменчивость популяционной структуры стеблевых мотыльков (Ostrinia spp.) на двудольных растениях-хозяевах и факторы, ее определяющие. Зоологический журнал, 1994, 73(3): 47-59.

14. Trnka M., Muška F., Semerádová D., Dubrovský M., Kocmánková E., Žalud Z. European corn borer life stage model: regional estimates of pest development and spatial distribution under present and future climate. Ecological Modelling, 2007, 207(2-4): 61-84 (doi: 10.1016/j.ecolmodel.2007.04.014).

15. Reardon B.J., Sumerford D.V., Sappington T.W. Impact of trap design, windbreaks, and weather on captures of European corn borer (Lepidoptera: Crambidae) in pheromone-baited traps. Journal of Economic Entomology, 2006, 99(6): 2002-2009 (doi: 10.1093/jee/99.6.2002).

16. Maiorano A. A physiologically based approach for degree-day calculation in pest phenology models: the case of the European corn borer (Ostrinia nubilalis Hbn.) in Northern Italy. International Journal of Biometeorology, 2012, 56(4): 653-659 (doi: 10.1007/s00484-011-0464-z).

17. Waligyra H., Weber A., Skrzypczak W., Chwastek E. The effect of weather conditions on corn smut infection and European corn borer infestation in several cultivars of sweet corn. Romanian Agricultural Research, 2014, 31: 357-364.

18. Букзеева О.Н., Поляков И.Я. Фазы динамики популяций стеблевого мотылька и модели их прогноза. В сб.: Теория, методы и технология автоматизации фитосанитарной диагностики. СПб, 1993: 115-124.

19. Фролов А.Н. Динамика численности и прогноз массовых размножений вредных насекомых: исторический экскурс и пути развития. Аналитический обзор. Вестник защиты растений, 2017, 4(94): 5-21.

20. Фролов А.Н., Букзеева О.Н. Кукурузный мотылек: прогноз развития, методы учета. Защита и карантин растений, 1997, 4: 38-39.

21. Гаркушка В.Г., Грушевая И.В., Фролов А.Н. Динамика многолетних оценок устойчивости гибридов кукурузы к кукурузному мотыльку Ostrinia nubilalis Hbn. в экологических испытаниях НПО «КОС-МАИС». Вестник защиты растений, 2018, 3(97): 15-17.

22. Фролов А.Н., Малыш Ю.М. Плотность размещения и смертность яиц и гусениц младших возрастов кукурузного мотылька на растениях кукурузы. Вестник защиты растений, 2004, 1: 42-55.

23. Carey J.R. Insect biodemography. Annual Review of Entomology, 2001, 46: 79-110 (doi: 10.1146/annurev.ento.46.1.79).

24. Henderson P.A., Southwood T.R.E. Ecological methods. John Wiley \& Sons, 2016.

25. Cardinal A.J., Lee M., Guthrie W.D., Bing J., Austin D.F., Veldboom L.R., Senior M.L. Mapping of factors for resistance to leaf-blade feeding by European corn borer (Ostrinia nubilalis) in maize. Maydica, 2006, 51(1): 93-102.

26. Dillehay B.L., Calvin D.D., Roth G.W., Hyde J.A., Kuldau G.A., Kratochvil R.J., Russo J.M., Voight D.G. Verification of a European corn borer (Lepidoptera: Crambidae) loss equation in the major corn production region of the Northeastern United States. Journal of Economic Entomology, 98(1): 103-112 (doi: 10.1093/jee/98.1.103).

27. Ma B.L., Subedi K.D. Development, yield, grain moisture and nitrogen uptake of Bt corn hybrids and their conventional near-isolines. Field Crops Research, 2005, 93(2-3): 199-211 (doi: 10.1016/j.fcr.2004.09.021).

28. Bode W.M., Calvin D.D. Yield-loss relationships and economic injury levels for European corn borer (Lepidoptera: Pyralidae) populations infesting Pennsylvania field corn. Journal of Economic Entomology, 1990, 83(4): 1595-1603 (doi: 10.1093/jee/83.4.1595).

29. Showers W.B., Hellmich R.L., Derrick-Robinson M.E., Hendrix W.H. Aggregation and dispersal behavior of marked and released European corn borer (Lepidoptera: Crambidae) adults. Environment Entomology, 2001, 30(4): 700-710 (doi: 10.1603/0046-225X-30.4.700).

30. Фролов А.Н. Биотические факторы депрессии кукурузного мотылька. Вестник защиты растений, 2004, 1: 37-47.

31. Velasco P., Revilla P., Monetti L., Butryn A., Ordás A., Malvar R.A. Corn borers (Lepidoptera: Noctuidae, Crambidae) in Northwestern Spain: population dynamics and distribution. Maydica, 2007, 52(2): 195-203.

32. Keszthelyi S. Flight dynamics analysis of the European corn borer (Ostrinia nubilalis (Hübner)) populations in Hungary from the second part of the twentieth century until the present. Archives of Phytopathology and Plant Protection, 2010, 43(13): 1286-1294 (doi: 10.1080/03235400802425713).

33. Maiorano A. A physiologically based approach for degree-day calculation in pest phenology models: the case of the European corn borer (Ostrinia nubilalis Hbn.) in Northern Italy. International Journal of Biometeorology, 2012, 56(4): 653-659 (doi: 10.1007/s00484-011-0464-z).

34. Kocmánková E., Trnka M., Eitzinger J., Formayer H., Dubrovský M., Semerádová D., 
Žalud Z., Juroch J., Možný M. Estimating the impact of climate change on the occurrence of selected pests in the Central European region. Climate Research, 2010, 44(1): 95-105 (doi: 10.3354/cr00905).

35. Peterson R.K., Davis R.S., Higley L.G., Fernandes O.A. Mortality risk in insects. Environmental Entomology, 2009, 38(1): 2-10 (doi: 10.1603/022.038.0102).

36. Фролов А.Н. Динамика численности кукурузного мотылька и ее прогноз. Бюллетень Московского общества испытателей природы. Отдел биологический, 2006, 111(1): 10-14.

ФГБНУ Всероссийский НИИ защиты растений, 196608 Россия, г. Санкт-Петербург - Пушкин, ш. Подбельского, 3, e-mail: entomology@vizr.spb.ru,grushevaya_12@mail.ru $₫$
Поступила в редакцию 27 марта 2019 года

\title{
ROLE OF METEOROLOGICAL FACTOR IN LONG-TERM POPULATION DYNAMICS OF THE EUROPEAN CORN BORER, Ostrinia nubilalis Hbn., IN KRASNODAR AREA: THE ANALYSIS OF LIFE TABLES
}

\author{
A.N. Frolov, I.V. Grushevaya
}

All-Russian Research Institute of Plant Protection, 3, sh. Podbel'skogo, St. Petersburg, 196608 Russia, e-mail entomology@vizr.spb.ru ( $\square$ corresponding author), grushevaya_12@mail.ru ORCID:

Frolov A.N. orcid.org/0000-0002-6942-9951

The authors declare no conflict of interests

Grushevaya I.V. orcid.org/0000-0003-4751-5442

Received March 27, 2019

doi: 10.15389/agrobiology.2020.1.184eng

\section{Abstract}

The European corn borer, Ostrinia nubilalis Hbn. is one of the most dangerous pests of maize. Though weather, mostly air temperature and humidity, demonstrate their important influence on distribution, population level and development terms of the European corn borer, the accuracy of forecasting models remains rather low to predict pest population dynamics. The aim of our work consists in the comparison of meteorological data with the demographic indicators characterizing long-term population fluctuations in the European corn borer to identify the most significant meteorological criteria for the forecast of pest population dynamics. Observations of insect population dynamics conducted during 1994-2018 on maize fields in vicinity of village Botanika (Gulkevichi

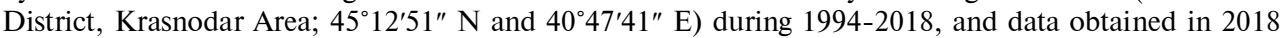
were only used for verification of the dependence established on data array for 1994-2017. We estimated density of insect population at all stages of life cycle from egg to adult. The meteorological information was obtained from the Otrado-Kuban meteorological station located in the center of the territory of the test field location. Mortality for the different periods of insect development (eggs, I-II and III-V instar larvae, pupae, adults) was estimated as $\mathrm{K}=\log \mathrm{N}_{1}-\log \mathrm{N}_{2}$, where $\mathrm{N}_{1}$ and $\mathrm{N}_{2}$ are density of insects for the corresponding periods. Mortality for generation was calculates as $K=\log N_{o}-\log N_{f}$, where $N_{o}$ and $N_{f}$ is density of eggs and egg-laying females of the current generation. The breeding index per generation was calculated as $I=N_{t+1} / N_{t}$, where $N_{t}$ and $\mathrm{N}_{t+1}$ is density of eggs for the current $(\mathrm{t})$ and the following $(t+1)$ generation, respectively. Two generations of the European corn borer annually develop in Krasnodar area, and size of population during the first generation usually grows, while those in second generation decreases. The demographic characteristics of insect statistically significant correlate with meteorological factors only during time interval from the third decade of May to the first decade of June when the peak of egg oviposition and mass hatching of I instar larvae of the first pest generation usually occur. Egg mortality shows the closest negative correlation with air temperatures and positive correlation with moisture (water drops and vapor). No association of demographic indicators with meteorological factors during oviposition and hatching of second-generation larvae was found probably due to formation of high and dense maize crops with a microclimate favorable for insect development. Thus, the data obtained demonstrate that the last decade of May - the first decade of June is the only critical period during the European corn borer development in the region. Based on the findings, we drown a 3D linear contour diagram of the European corn borer first generation egg mortality as dependent on mean daily air temperature and relative atmospheric humidity during the last decade of May. This dependence is of interest in terms of an improved model for short-term forecast of pest population dynamics in Krasnodar Area.

Keywords: European corn borer, population dynamics, demography, egg mortality, air temperature, air humidity, Krasnodar Area. 